\title{
DISCOID LATERAL MENISCUS INCIDENCE DURING KNEE ARTHROSCOPY
}

Miodrag Glisic ${ }^{1}$, Zoran Blagojevic ${ }^{1}$, Branko Ristic ${ }^{2}$, Vladan Stevanovic ${ }^{1}$, Aleksandar Matic ${ }^{2}$, Zelimir Jovanovic ${ }^{1}$ ${ }^{1}$ Institute for Orthopaedic Surgery Diseases „Banjica“, Belgrade, Serbia

${ }^{2}$ Clinic of Orthopedics and Traumatology, Clinical Center Kragujevac, Kragujevac, Serbia

\author{
DISKOIDNI LATERALNI MENISKUS - INCIDENCA \\ KOD ARTROSKOPIJE KOLENA \\ Miodrag Glišić ${ }^{1}$, Zoran Blagojević ${ }^{1}$, Branko Ristić ${ }^{2}$, Vladan Stevanović ${ }^{1}$, Aleksandar Matić ${ }^{2}$, Želimir Jovanović ${ }^{1}$ \\ ${ }^{1}$ Institut za ortopedsko-hirurške bolesti “Banjica”, Beograd, Srbija \\ ${ }^{2}$ Klinika za ortopediju i traumatologiju, Klinički centar Kragujevac, Kragujevac, Srbija
}

\section{ABSTRACT}

Discoid meniscus is a morphological anomaly of the lateral meniscus that appears in 1-5\% of meniscectomies. A precise diagnosis remains difficult to make, and many dilemmas hinder effective treatment.

To evaluate the incidence of discoid meniscus in patients who underwent knee arthroscopy, as well as the discoid meniscus type, follow-up problems, combined knee lesions, and postoperative results.

This retrospective study included 1357 patients who received knee arthroscopy during the period between January 2007 and December 2013. We analysed the discoid meniscus incidence, sex distribution, type distribution (Monllau classification), noted preoperative symptomatology, rupture incidence and type (O'Connor classification), anomaly presence and other intra-articular lesion correlations. The IKDC score was used to evaluate the operative treatment results.

The DLM incidence was $1.03 \%$. The most common type of discoid meniscus was complete 5 (35.71\%). The dominant symptom was pain, which was reported by 12 (85.71\%) patients. Eleven (78.57\%) patients exhibited ruptures, and the most common type was horizontal, which was reported in $4(36.36 \%)$ cases. The number of ruptures was significantly higher in patients older than 18 (9 patients; 90\%), compared to those younger than 18 (2 patients; 40\%). Operative treatment resulted in an improvement for all patients in terms of subjective symptom reduction.

The incidence of DLM in our study was $1.03 \%$, and the dominant symptom was pain in the knee (85.71\%). The most common lesion of the meniscus was a horizontal split, primarily in patients older than 18 years. Patients also presented with joint intra-articular lesions; the most common type was ACL rupture. In all patients, an improved postoperative IKDC score was reported.

Key words: discoid meniscus, knee arthroscopy, saucerization

\section{SAŽETAK}

Diskoidni meniskus je morfološka anomalija lateralnog menisusa koja se srece u 1 - 5\% meniscektomija. I dalje postoje poteškoće u preciznoj i tačnoj dijagnostici kao i dileme o najboljem načinu rešavanja

Pokazati učestalost diskoidnih meniskusa kod pacijenata kojima je radena artroskopija kolena, tipove diskoidnog meniskusa, prateće tegobe, udružene lezije kolena, postoperativni rezultat.

Retrospektivna studija je obuvatila 1357 pacijenata kojima je u periodu od januara 2007. godine do decembra 2013. godine radena artroskopija kolena. Analizirana je incidenca diskoidnog meniskusa, raspodela prema polu, tipu (Monllau klasifikacija), notirana je preoperativna simptomatologija, incidenca i tip raskida (O'Conor klasifikacija), korelacija prisustva anomalije i drugih intraartikularnih lezija. IKDC skor je korišćen radi procene rezultata operativnog lečenja.

Incidenca javljanja diskoidnog meiskusa bila je 1.03\%. Kod 5 (35.71\%) pacijenta je bio kompletni tip diskoidnog meniskusa. Dominantni simptom bio je bol - 12 ( $85.71 \%)$ pacijenata. Raskid je postojao kod 11 ( $78.57 \%)$ pacijenata $i$ to najčešće horizontalni 4 (36.36\%) slučaja. Značajno više raskida kod starijih od 18 godina - 9 (90\%) u odnosu na mlade od 18 goidna - 2 (40\%). Operativno lečenje dovelo je do poboljšanja kod svih pacijenta u smislu subjektivnog smanjenja tegoba.

Incidenca javljanja DLM-a u našoj studiji je 1,03\% od čega je $35.71 \%$ kompletan tip DLM. Dominantan simptom je bio bol u kolenu (85, 71\%). Najčešća lezija meniskusa je bio horizontalni rascep $i$ to prevashodno kod pacijenata starijih od 18 godina. Više je bilo pacijenata sa uduženom intraartikularnom lezijom, najčeśća je bila ruptura LCA. Kod svih pacijenata došlo je do popravljanja IKDC skora postoperativno.

Ključne reči: diskoidni meniskus, artroskopija kolena, saucerizacija 


\section{ABBREVIATIONS}

DLM - Discoid lateral meniscus IKDC - International Knee Documentation Committee
LCA (ACL) - Ligamnetum cruciatum anterior SPSS - Statistical Package for the Social Sciences MRI - Magnetic resonance imaging

\section{INTRODUCTION}

Discoid lateral meniscus (DLM) represents the most common structural and morphological anomaly of the knee meniscus. $(1,2)$ The first DLM description was reported by Young in 1889. (3) Thus far, research has indicated the existence of clear racial differences in the incidence of this morphological anomaly, with the Asian population exhibiting the highest incidence (from 9.1\% to $16.6 \%$ ), while the European population demonstrates a somewhat lower incidence of DLM (from 0.4\% to 5\%). $(4,5,6)$ In 1979 , Watanabe et al. established a classification system in which DLM was divided into three groups: complete (a), incomplete (b) and Wrisberg type (c), and, in 1998, Monllau et al. suggested adding "ring-shaped" lateral meniscus $(d)$ as the fourth group in this classification. $(7,8)$ The most common lesions are complete and incomplete, which are usually asymptomatic and represent incidental findings unless combined with meniscus lesions.

The imprecise symptomatology and common asymptomatic presentation of DLM renders this meniscus anomaly difficult to diagnose. Common symptoms that occur in DLM cases include pain, popping and movement limitation related to knee extension. Ultrasonographic imaging of the menisci may demonstrate a wide and irregularly shaped lateral discoid meniscus in type 1 and 2 discoid menisci with an overall accuracy of more than $70 \%$. $(9,11)$. Magnetic resonance imaging (MRI) is widely used to diagnose musculoskeletal pathologies affecting the knee. The most accurate criterion for the diagnosis of discoid meniscus using MRI is the ratio of the minimal meniscal width to maximal tibial width. This ratio provided a sensitivity and

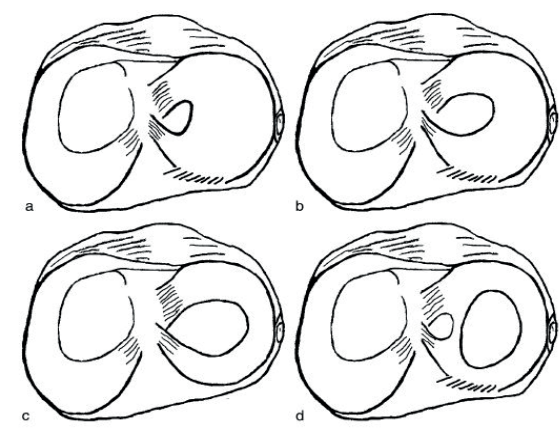

Monllau classification of DLM [8] specificity of $95 \%$ and $97 \%$, respectively, even when torn menisci were present. $(10,17)$

Discoid lateral meniscus is a common incidental finding during arthroscopy of the knee. In 1957, Kaplan recommended the total meniscectomy of the discoid meniscus (31). Long-term follow-up points to a greater prevalence of osteoarthritis changes after total meniscectomy, and many authors have since recommended partial arthroscopic meniscectomy. (13, 14, 15, 34, 35) Rosenberg et al. (1987) described a case in which a Wrisberg ligament type of DLM was reattached peripherally after central partial meniscectomy (32). The currently used treatment method consists of $\mathrm{f}$ arthroscopically assisted partial meniscectomy. DLM remodelling, including processing of all unstable and separated meniscus parts (saucerization), must be performed. $(16,17,18)$ The treatment of asymptomatic DLM by partial meniscectomy and saucerization is not recommended because the knees of such patients are considered to be biomechanically adapted to DLM; therefore, the disturbance of such biomechanics by partial meniscectomy would favours the more rapid occurrence of degenerative knee changes. $(19,38)$

\section{AIM}

Because doubts remain regarding the diagnosis and treatment of these rare anatomical anomalies, the aim of this paper was demonstrate the frequency of DLM in our patient population, diagnosed types of DLM, associated symptoms, associated intra-articular knee lesions, and results of partial meniscectomy.

\section{MATERIAL AND METHODS}

This retrospective study was conducted in IOS "Banjica” from January 2007 to December 2013, and we analysed 1357 patients who underwent arthroscopic knee surgery. Symptoms such as joint pain, popping, and movement limitations and McMurray test results were noted preoperatively in medical documents.

Indications for arthroscopic surgery were defined after presenting each patient to the Department Consulting Body and were based on subjective problems, clinical results and additional diagnostic procedures. Standard knee plain roentgenograms were performed in all cases, and MRI was performed for 8 patients. 


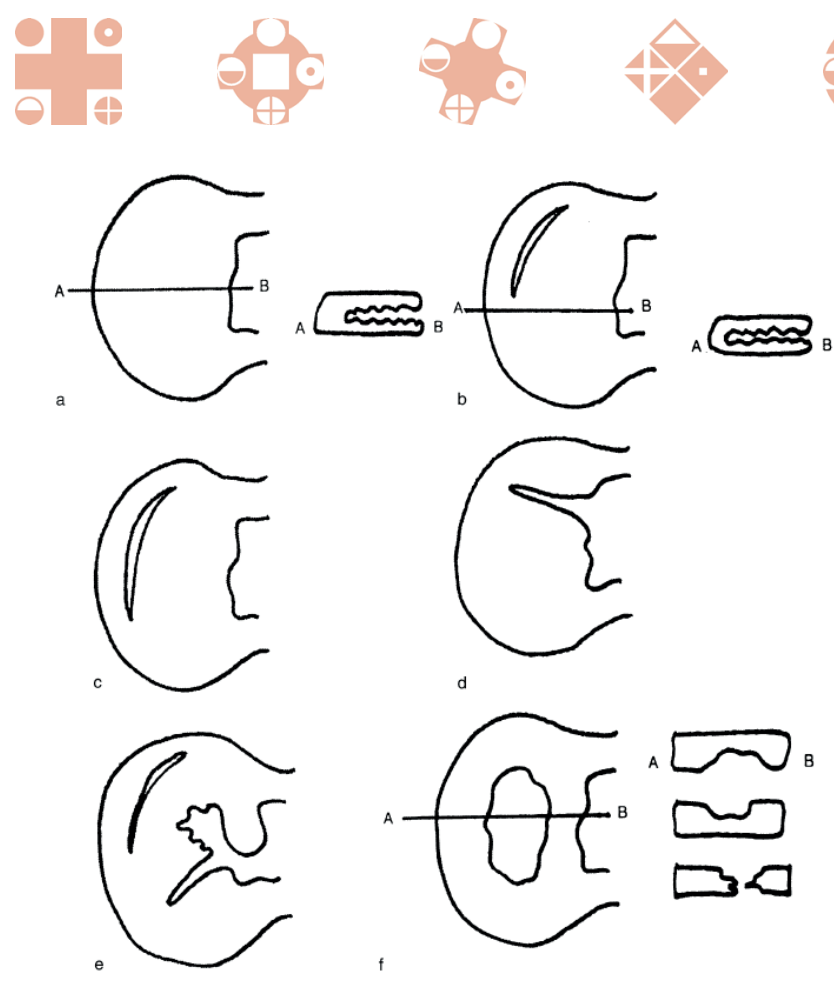

O'Connor's classification of DLM ruptures: a) simple horizontal, b) combined horizontal, c) longitudinal rupture, d) transverse rupture, e) multiple rupture, f) central rupture [17]

The demographic data were obtained from the institute's medical documents. The discoid lateral meniscus type, as well as lesion type (if any was observed), was noted postoperatively in medical documents. All patients with diagnosed DLM received saucerization, i.e., partial meniscectomy.

We analysed the DLM incidence, DLM distribution according to Monllau's classification (8), patient sex, preoperative symptoms, and type of DLM rupture according to O'Connor classification (17), as well as the correlation between the presence of DLM and other intra-articular lesions.

Patients were included in the study according to the order in which they were admitted to the hospital and underwent surgery. The criterion for inclusion was the intraoperative finding of DLM. All patients were regularly invited to check-ups by the end of rehabilitation. The data were statistically analysed in SPSS software, which was used for descriptive statistics. The obtained results are shown as graphs.

\section{RESULTS}

Out of 1357 total arthroscopies performed in IOS "Banjica" during the period from January 2007 to December 2013, DLM was diagnosed in 14 (1.03 \%) patients. On average, the patients were 23 years old (from 10 to 43). Six patients were male $(42.86 \%)$, and 8 were female (57.14\%). (Graph 1)

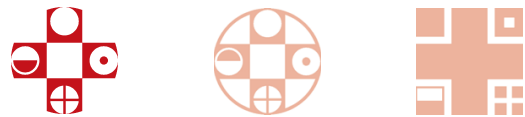

Distribution by sex

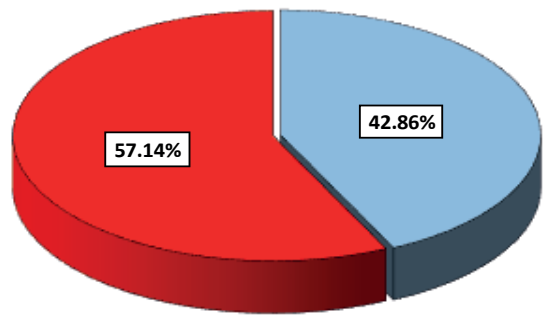

$\square$ male $\square$ female

Graph 1. Patient distribution by sex

According to Monllau's classification (8), out of $14 \mathrm{di}$ agnosed DLMs, 7 cases (50\%) were complete, 5 (35.71\%) incomplete, 1 (7.14\%) Wrisberg type and 1 (7.14\%) "ringshaped" type. In 8 (57.14 \%) cases, DLM was diagnosed in the right knee, while DLM was present in 6 (42.86\%) left knee cases. (Graph 2)

The anamnestic data on knee trauma was positive for $8(57.14 \%)$ patients. Pain was the dominant symptom that was present in 12 patients $(85.71 \%)$, and these individuals reported palpation painful sensitivity in the projection of the lateral joint gap. Popping and occasional knee movement limitations were present in $9(64.28 \%)$ patients. On average, 4 months passed between the onset of symptoms to arthroscopy.

Out of 14 diagnosed DLMs, 11 (78.57 \%) cases were combined with meniscus lesions. Using O'Connor's classification, we diagnosed 4 (36.36\%) horizontal fissures, $3(27.27 \%)$ vertical fissures, $2(18.18 \%)$ radial fissures, 1 (9.09\%) combined rupture and 1 (9.09\%) multiple rupture. In patients over the age of 18, combined DLM lesions were diagnosed more often ( 9 patients; $90 \%$ ) than in patients younger than 18 years of age (2 patients; $40 \%)$. This difference demonstrated strong statistical significance $(p<$ 0.0005). (Graph 3 \& Graph 4)

In $5(35.71 \%)$ cases, another combined intra-articular lesion besides DLM was found: in 3 (21.42\%) cases, lesions of the anterior cruciate knee ligament were observed; 1 (7.14 $\%)$ patient was diagnosed with chondral lesion and 1 (7.14\%) individual exhibited both damage of the anterior cruciate ligament and chondral lesion. (Graph 5 \& Graph 6)

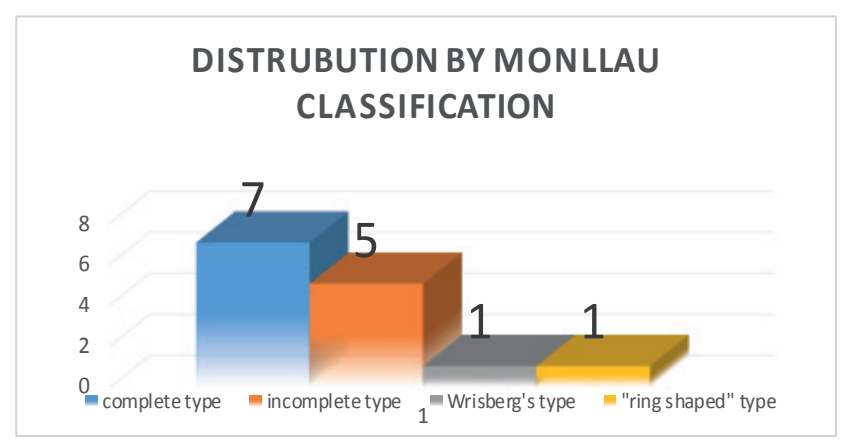

Graph 2. Patient distribution by Monllau classification 


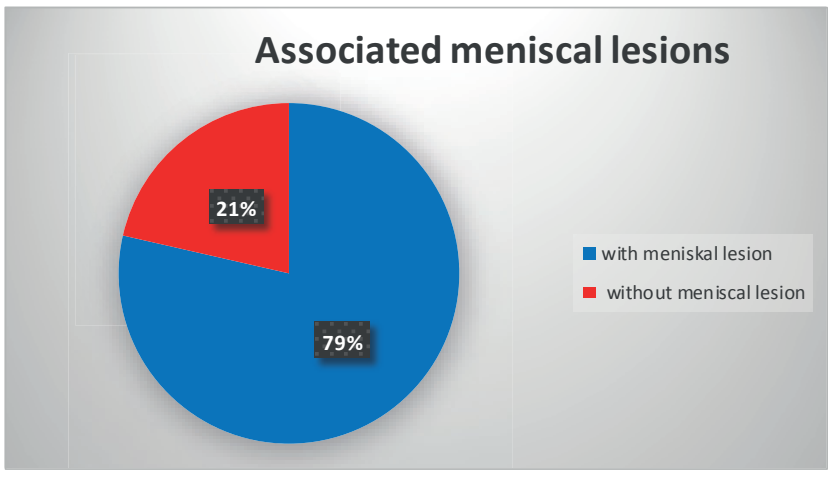

Graph 3. Incidence of associated meniscal lesions

\section{MENISCAL LESIONS}

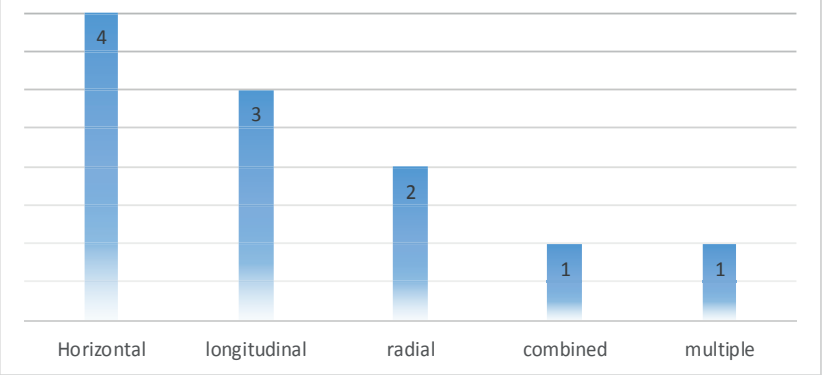

Graph 4. Type of meniscal lesion

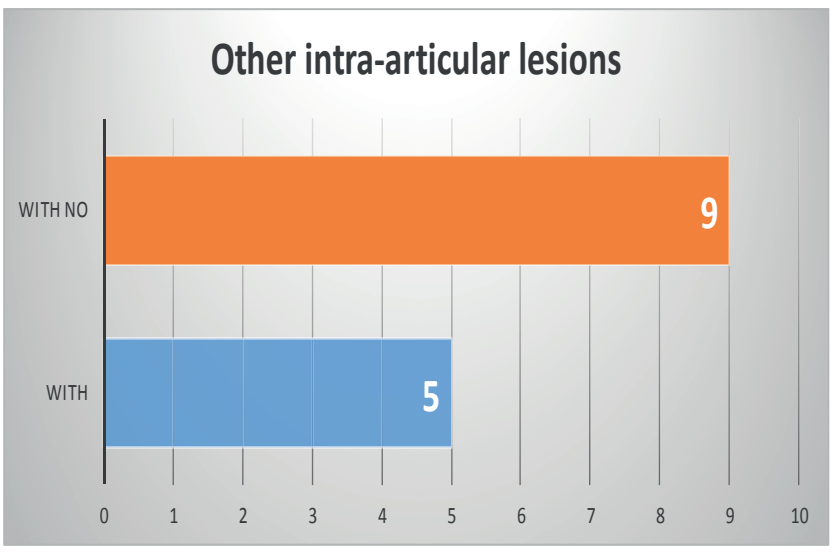

Graph 5. Incidence of other intra-articular lesions

\section{TYPES OF INTRA - ARTICULAR LESIONS}

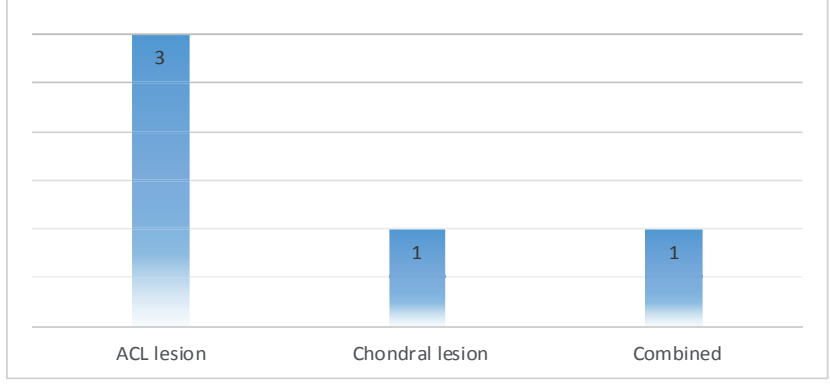

Graph 6. Type of intra-articular lesion
On average, the obtained results were collected over 6 months of monitoring (from 3 to 9 months). All patients recovered successfully after rehabilitation, and they continued their normal life activities. The average preoperative IKDC score (20) of all patients was 70; postoperatively, the average patient IKDC score improved to 90 . No complications were observed during intervention and the immediate postoperative course, and no other delayed complications were reported.

\section{DISCUSSION}

The cause of discoid menisci has been a matter of considerable discussion. In 1948, Smillie (21) postulated that the discoid shape is a normal stage in the developing embryo and that failure of absorption of the central portion will persist during the foetal state. Kaplan (22) claimed that insufficient posterior meniscal attachment to the tibia causes increased meniscal excursion during flexion and extension and that repetitive microtrauma subsequent to this increased mobility produces morphological changes. Complete and incomplete types of DLM could result from the cessation of absorption during foetal life, while the Wrisberg type is mainly hypermobile and lacks the posterior attachment to the tibial plateau.

The incidence rate of $1.03 \%$ recorded in our study falls in the incidence range $0.4-5 \%$ reported by arthroscopic studies in the Caucasian population. $(6,23,24)$ Much higher incidence rates have been reported among Indian (5.8\%), Korean $(9.1-10.5 \%)$ and Japanese $(16.6 \%)$ patients $(25,26,4,5)$. The reasons for this prevalence distribution are unknown.

No statistically significant differences were observed in terms of the sex of individuals diagnosed with DLM (8:6 in favour of females). In a Swedish report by Abertsson et al., of 29 patients with DLM, 11 were male and 18 female.(23) In another study performed in India by Sriptahi et al., 41 male and 46 female patients (out of 87 patients) with DLM were studied. (9) Thus, these studies also failed to find a significant difference in the male-to-female ratio.

We use Monllau's classification (8) of the DLM type in our study, and the complete type was the dominant one (7 cases; $50 \%$ ), followed by incomplete (5 cases; $35.71 \%$ ) and then by Wrisberg type (1 case; 7.14\%) and "ring-shaped" meniscus (1 case; $7.14 \%$ ). In a Greek study analysing discoid dysmorphy among 39 patients with DLM, 23 cases were attributed to complete type DLM, 15 were incomplete and Wrisberg type was observed in one case. (6) A Scandinavian report on this subject indicated that the complete and incomplete types of DLM were dominant (23). In their study, Sriptahi et al. reported $69.4 \%$ complete type, $26.3 \%$ incomplete type, $4.2 \%$ "ring-shaped" discoid lateral menisci and no Wrisberg ligament type cases (9). Fabrizio et al. and O. Ahmet Atay et al. also reported similar incidences. $(27,28)$

All patients in our study diagnosed with DLM reported preoperative problems involving popping, pain, occasional swelling and knee blockade. The dominant symptom was knee pain in $85.71 \%$ of individuals. Palpatory pain in the 
projection of the lateral joint line was more frequent than knee popping, but no statistically important differences were observed in distribution. Palpatory pain and knee pain in general could be an indirect indicator of DLM lesions; therefore, the incidence of combined meniscus lesions with DLM findings was $85.72 \%$. Papadopoulos at al. also found knee pain to be the dominant symptom in $90 \%$ of cases. $(6,36,37,39)$

Changes in the morphology and vascularization of DLM render the condition more prone to mechanical stress; therefore, arthroscopic findings of combined meniscus lesions are relatively common. (33) We detected DLM combined with lesions of the meniscus itself in 11 $(85.72 \%)$ cases, and the incidence was statistically higher in patients over the age of 18 (90\%). In our study, horizontal, vertical, radial, and transversal type lesions were present. Interestingly, only slightly more than half of the patients (57.14\%) mention earlier knee trauma. Similar results were reported by Sripathi et al. (9)

Partial meniscectomy was performed on all patients because symptomatic DLM was identified. After the end of treatment and a standard rehabilitation protocol for meniscectomy, all patients reported subjective improvements in knee problems. The patients' IKDC score results were higher after surgery.

In 5 (35.71\%) of our patients, in addition to DLM, combined lesions of the anterior cruciate ligament (ACL) in were diagnosed 3 patients $(21.42 \%)$, chondral lesions in 1 (7.14 \%) patient, and both ACL damage and chondral lesions in $1(7.14 \%)$ patient.

\section{CONCLUSION}

The incidence of DLM in our study was $1.03 \%$, and the dominant symptom was pain in the knee $(85.71 \%)$. The most common lesions of the meniscus were a horizontal split, primarily in patients older than 18 years. Certain patients also presented with joint intra-articular lesions, the most common of which was ACL rupture. All patients reported improved IKDC scores after surgery.

The frequency of meniscal malformations in the population is difficult to determine because a number of these cases are asymptomatic. This study evaluated the incidence of DLM in knee arthroscopy and not the incidence in the general population. Arthroscopy remains an invasive surgical method. MRI screening may represent a better means of precisely determining the incidence of these anomalies in the general population.

\section{REFERENCES}

1. Wood GW, Whelan JM. Discoid meniscus. Clin Sports Med 1990;9:695-706.

2. Jordan M. Lateral meniscal variants: Evaluation and treatment. J am Acad Orthop Surge 1996;2:239-53.
3. Young RB. The external semilunar cartilage as a complete disc. In: Cleland J, et al., eds. Memoris and memoranda in anatomy. Vol I. London: Williams and Norgate, 1889;179.

4. Ikeuchi H. Arthroscopic treatment of the discoid lateral meniscus:Technique and long term results. Clin Orthop 1982;167:19-28.

5. Lu Y, Li Q, Hao J Torn discoid lateral meniscus treated with arthroscpic meniscectomy: observation in 62 knee. Chin Med J (Engl) 2007; 120:211-15.

6. Papadopoulos A, Karathanasis A, Kirkos JM, Kapetanos GA Epidemiologic, clinical and arthroscopic study of the discoid meniscus variant in Greek population. Knee Surg Sports Traumatol Arthrosc. 2009 Jun;17(6):600-6.

7. Watanabe M, Takada S, Ikeuchi H. Atlas of arthroscopy.2nd ed. Tokyo: Igaku Shoin, 1969.

8. Monllau JC, Leon A, Cugat R, Ballester J. Ring-shaped lateral meniscus. Arthroscopy 1998;14:502-04.

9. P. Sripathi Rao, M.S., Sharath K. Clinical, Radiologic, and Arthroscopic Assessment of Discoid Lateral Meniscus. Arthroscopy: The Journal of Arthroscopic and Related Surgery, 2001, 17(3): 275-77.

10. Samoto N, Kozuma M, Tokuhisa T, Kobayashi K Diagnosis of discoid lateral meniscus of the knee on MR imaging. Magn Reson Imaging 2002, 20:59-64.

11. Najafi J, Bagheri S, Lahiji FA The value of sonography with micro convex probes in diagnosing meniscal tears compared with arthroscopy. J Ultrasound Med 2006, 25:593-97.

12. Washington ER, Root L, Liener UC. Discoid lateral meniscus in children: Long-term follow-up after excision. J Bone JointSurg Am 1995;77:1357-61.

13. Kobayashi A, Uezaki N, Mitsuyasu M. Discoid meniscus of the knee joint. Clin Orthop 1975;10:10-24.

14. Raber DA, Friederich NF, Hefti F. Discoid lateral meniscus in children: Long-term follow-up after total meniscectomy.J Bone Joint Surg Am 1998;80:1579-86.

15. Fujikawa K, Iseki F, Mikura Y. Partial resection of the discoid meniscus in the child's knee. J Bone Joint Surg Br 1981;63:391-95.

16. Vandermeer RD, Cunningham FK. Arthroscopic treatment of the discoid meniscus: Results of long-term follow-up. Arthroscopy1989;5:101-9.

17. Shahriaree H, O'Connor's textbook of arthroscopic surgery. Lippincott, Philadelpia, 1984, 318-321.

18. Young-Goo Kim, Joo-Chul Ihn, Seomg-Ki Park, HeeSoo Kyung . An Arthroscopic analysis of lateral meniscal variant and a comparison with MRI findig. Knee Surg Sports Traumatol Arthrosc 2006 14:20-6.

19. Okazaki $K^{1}$, Miura H, Matsuda S, Hashizume M, Iwamoto Y. Arthroscopic resection of the discoid lateral meniscus: long-term follow-up for 16 years.Arthroscopy. 2006 Sep;22(9):967-71.

20. Irrgang JJ, Anderson AF, Boland AL et al Development and validation of the International Knee Documentation Committee subjective knee form. Am J Sports Med. 2001;29(5):600-13.

21. Smillie I The congenital discoid meniscus. J Bone Joint Surg 1948, 30:671-82. 
22. Kaplan EB Discoid lateral meniscus of the knee joint. Bull Hosp Joint Dis 1955, 16:111-24.

23. Abertsson M, Gillquist J, Discoid lateral menisci: a report of 29 cases. Arthroscopy 1988, 4(3):211-14.

24. Washington ER, Root L, Liener UC Discoid lateral meniscus in children: long-term follow up after excision. J Bone Joint Surg Am 1995, 77:1357-61.

25. Rao SP, Rao SK, Rajesh P Clinical, Radiologic and arthroscopic assessment of discoid lateral meniscus. Arthroscopy 2001, 17(3):275-77.

26. Kim SJ, Lee YT, Kim DW Intraarticular anatomic variants associated with discoid meniscus in Koreans Clin Orthop Relat Res 1998, 356:202-07.

27. Fabrizio Pellacci, M.D., Giorgio Montanari, M.D. Lateral Discoid Meniscus: Treatment and Results Arthroscopy: The Journal of Arthroscopic and Related Surgery 1992, 8(4):pp 526-30.

28. Ahmet Atay, M.D., M. Nedim Doral, M.D. Management of Discoid Lateral Meniscus Tears:Observations in 34 Knees. Arthroscopy: The Journal of Arthroscopic and Related Surgery, 2003, 19(4): 346-52.

29. Christopher R. Good, M.D., Daniel W. Green, M.D., Arthroscopic Treatment of Symptomatic Discoid Meniscus in Children: Classification, Technique, and Results. Arthroscopy: The Journal of Arthroscopic and Related Surgery, 2007, 23(2): 157-63.

30. Aichroth PM, P.D., Marx CL., Congenital discoid lateral meniscus in children. A follow-up study and evolution of management. J Bone Joint Surg Br, 1991 Nov. 73(6): p. 932-6.
31. Kaplan EB. Discoid lateral meniscus of the knee joint: nature, mechanism and operativ treatment. J Bone Joint surg (Am) 1957 39-A.

32. Rosenberg TD, Paulos LE, Parker RD, HaRNER cd, Gurley WD. Discoid lateral meniscus: case report of arthroscopic attachment of symptomatic Wrisberg type. Arthroscopy 1987;3:277-82.

33. Anestis Papadopoulos, M.D., Ph.D., John M. Kirkos, M.D., Ph.D., and George A. Kapetanos, M.D., Ph.D. Histomorphologic Study of Discoid Meniscus. Arthroscopy, 2009, 25(3): 262-68.

34. Dasic Z, Radoicic D. Arthroscopy partial medial meniscectomy.Vojnosanitetski pregled, 2011, 68(9): 774-78

35. Stevanovic V, Blagojevic Z. Chronic lesions of LCA and associated knee injury.Acta orthopaedica Iugoslavica, 2002, 33(1-2):107-11.

36. Micunovic L. Arthroscopy and its importance in the diagnosis of meniscal lesions. Srpski arhiv za celokupno lekarstvo, 2001, 129(3-4):94-96.

37. Timotijevic S, Vukasinovic Z, Bascarevic Z. The value of clinical and ultrasound findings in relation to the arthroscopic findings of acute injury of the medial meniscus of the knee.Srpski arhiv za celokupno lekarstvo, 2008, 136(1-2): 28-32.

38. Milenkovic S. Early osteoarthritis of knee after total meniscectomy in childhood. Acta medica Medianae, 2006, 45(1): 61-64.

39. Blagojevic Z. Arthroscopy in the diagnosis of joint disease.Balneoklimatologija, 2002, 26(1), 69-72. 